\title{
Mine Planning and Design for Mining Engineering learners at Wits University
}

\author{
by B. Genc and R. Mitra
}

\section{Synopsis}

The School of Mining Engineering (Wits Mining) at the University of the Witwatersrand (Wits) has a final-year course called 'Mine Design'. The objective of this course is to ensure that students utilize the knowledge gained not only during the four years of coursework, but also during their vacation work, to conduct a mine planning and design exercise at the prefeasibility study level.

The overall objective of the course is to enable the students to follow a rigorous method of ascertaining the technical and economic viability of a project. Any conclusion arrived at, either positive or negative, is acceptable provided that logical and quantifiable reasons are given. The students have to use mine planning software in order to complete the study. The setting up of a practical layout for a proposed mining operation, with the associated expenditure, will permit the students to make a substantiated recommendation regarding the viability of mining the deposit. In order to include ventilation aspects, only underground design projects are made available. Mine planning and design is done in groups, and each group prepares a coherent and professionally consolidated report and presentation that are presented to staff members, external examiners, and their peers.

To assist the students to complete the project, the fully-equipped Mine Design Laboratory is made available. This paper looks into the steps that are involved for a successful completion of the Mine Design course.

Keywords

mining education, mine planning and design, Wits Mining.

\section{Introduction}

Mine planning and design involves compiling and incorporating suitable geotechnical, geochemical, geological, mining, engineering, and economic data in order to establish an approach to exploit a specific mineral deposit within the legal and regulatory requirements (Fourie and van Niekerk, 2001). The aim of planning and design in mining operations is to enable extraction and processing of a mineral deposit at the desired market specification, at a minimum unit cost, and under the existing economic conditions (Fourie and van Niekerk, 2001). A number of professions such as engineering, science, and finance contribute either directly or indirectly to the completion of the mine planning and design process (Department of Minerals and Energy, 1997; Fourie and van Niekerk, 2001). Smith, Pearson-Taylor, and Andersen, (2006) reported that centralizing of strategic longterm planning with the aim to enable efficient involvement with the operations (strategic long-term planning) and the Executive Committee (strategic alignment, scenario development and evaluation) and capital investment prioritization was initiated at Anglo American Platinum to standardize ways of carrying out business and running operations. Smith and Pearson-Taylor (2006) illustrated, with a decision tree, a strategy from which a mining right plan is generated and the long-plan is extracted. The concepts of mine planning and design has been reported in long term production scheduling in both opencast and underground coal mines (Campell, 1994; Department of Minerals and Energy, 2001; Fourie and van Niekerk, 2001; Smith and Pearson-Taylor, 2006; Steffen, 1996).

According to Brophy et al. (2008), there is a particular focus on design-oriented teaching in engineering education. Design-oriented teaching deals with solving complex problems, which entails a range of technical and generic skills as opposed to traditional engineering education. Saydam and Mitra (2013) discussed in detail the implementation of project-based courses in mining engineering education.

Wits Mining offers the BSc degree in Mining Engineering, which is a fixed curriculum programme, i.e. there are no elective courses offered. The four-year degree programme offers a number of courses covering various aspects of mining engineering. The Mine Design course, one of the fourth-year courses, has two components:

> Mine design report

> Mine design presentation.

* School of Mining Engineering, University of the Witwatersrand, South Africa.

(c) The Southern African Institute of Mining and Metallurgy, 2018. ISSN 2225-6253. This paper was first presented at the Society of Mining Professors 6th Regional Conference 2018, 12-13 March 2018, Birchwood Hotel and Conference Centre, Johannesburg, South Africa. 


\section{Mine Planning and Design for Mining Engineering learners at Wits University}

In this course, the students have to use knowledge gained from courses in previous years and their vacation work to design a mine at a pre-feasibility study level. For this reason, the Mine Design course is also known as the 'capstone' course.

In line with the requirements of the Engineering Council of South Africa (ECSA), the Mine Design course addresses several Exit Level Outcomes (ELOS). The students are tested for report writing as well as presentation skills. The ELOs related to the Mine Design course are:

> Perform creative, procedural, and non-procedural design and synthesis of components, systems, works, products, or processes (ELO3)

> Design and conduct investigations and experiments (ELO4)

> Use appropriate engineering methods, skills, and tools, including IT (ELO5)

> Communicate effectively, both orally and in writing, to their peers, engineering audiences, and the community at large (ELO6)

> Demonstrate critical awareness of the impact of engineering activity on the social, industrial, and physical environment (ELO7)

- Work effectively as an individual, in teams and in multi-disciplinary environments, and take responsibility for their own work (ELO8)

> Engage in independent learning through welldeveloped learning skills (ELO9)

> Act professionally and ethically, exercise judgement, and take responsibility for their own work (ELO10)' (ECSA, 2018).

Furthermore, the students are also tested on the following graduate attributes for this course:

> Analysing information and working with information that may not be complete or working in unfamiliar design contexts

> Integrating a number of subjects into a single, coherent technical report

- Analysing alternatives and selecting the best option based on sound engineering and economic principles

- Applying mathematical analysis in deriving engineering designs

> Applying appropriate software and computer applications in an engineering field.

To help achieve all the above requirements, Wits Mining established a Mine Design Laboratory (MDL) in 2010. Although the MDL serves a number of purposes within the Wits Mining facilities, it also plays an important role in assisting students to complete the Mine Design Project (Genc and Cawood, 2012).

\section{Mine design course}

As part of the prerequisite for this 'capstone' final-year course, students have to pass all the subjects in their previous years of study. Furthermore, Wits Mining has established a strong foundation to conduct the Mine Design exercise since 1998. To assist students in their preparation for the Mine Design exercise, in 1997 a new course, 'Computerised Mine Design' was introduced in the third year in partnership with some of the leading mine planning software providers. In this course, the students are taught to use specific mine planning software so that it can be used in the following year during the Mine Design exercise.

\section{Mine design exercise}

As part of this assignment, students are provided with actual mine design projects from the industry taking into consideration the planning and design process during the life of the mine.

Studies reported by Fourie and van Niekerk (2001) and Steffen (1996) indicated that the mine planning and design process during the life of any mine involves five stages:

$>$ Obtaining data

> Data evaluation, mine planning and design

> Construction and development of the mine

$>$ Operations

> Mine closure.

The planning and design process related to the above stages involves factors such as identification of expected outcomes, planning and design expectations, risk identification, identification of planning and design limitations, data gathering, risk assessment, assessment of options, etc. (Fourie and van Niekerk, 2001).

The purpose of evaluation, planning, and design of a new mine is to analytically investigate the prospecting area with respect to the technical and economic viability of the project. Several investigations may be required as a mine project develops from the initial exploration and conceptual economic phase to the stage where a management decision is made to exploit a particular mineral deposit. Each stage involves an increasing amount of data, which may require a lot of time to prepare, and a higher degree of accuracy. According to the SAMREC Code (2016), for a mine planning and design process to be established, the investigation of the mineral deposit needs to progress through the following stages:

> Scoping study

> Pre-feasibility study

> Feasibility study.

The outcome of each study must be documented in such a way as to support the decision on whether to continue to the next stage of the mine project or not. The following required information pertaining to the studies mentioned above must be included in order to meet this requirement:

> Description of the project: Information regarding area of interest (AOI), roads, topography, weather, development plans of the mine and any processing amenities

> Geology: Full report of the AOI in terms of regional geology, initial reserve estimation, and target valuation

> Mining: Information regarding the depth of the mineral deposit, deposit geometry, proposed plan regarding how to mine the deposit, as well as plant and equipment requirements

> Processing: Description of the processing facilities

> Other operating needs: infrastructure (power and water), equipment, and spare parts availability

> Transportation system: Infrastructure of transportation facilities (roads, harbours, railway lines etc.).

> Towns and related facilities: Accommodation for workers, medical facilities, schools, etc. 


\section{Mine Planning and Design for Mining Engineering learners at Wits University}

Labour requirements: Availability of work force based on qualifications and skills

> Environmental protection: Detailed environmental impact assessment to minimize environmental damage in line with the environmental legislation

> Legal considerations: Compliance with the mining laws, taxation, foreign investment regulations etc.

> Economic analysis: Full cost analysis including labour, equipment, and other factors.

Every year, different commodities such as gold, coal, platinum, diamonds, and base metals are used in the Mine Design exercise. The benefit of having real design projects stems from the good relationship the School has with the mining industry. The Wits Mining team starts looking for possible projects a few months before the starting date of the exercise. After a project is identified, the exercise commences immediately after the fourth-year students' last examination, so that the students can focus solely on the design project. The Course Coordinator briefs the students about the project and divides the class into groups of five or six students. The groups are selected in a random manner. The students are briefed about the project location and given the necessary information such as mining boundaries, 3D orebody models, and geostatistical information, considering the fact that the students have limited time and manpower. Historically, the students used to create the 3D model using borehole data, and also used to do the geostatistical data analysis. However, since 2017, Wits Mining has decided to provide such information after considering the fact that the mining engineers do not create 3D orebody models in a workplace environment.

As part of the briefing, the students are also provided with a list of topics showing what is expected of the project report. The topics are listed in Table I. The students distribute the workload within their team and also are required to select a group leader, who is responsible for the overall management of the project (Table I).

The Course Coordinator also nominates a staff member for each of the topics in Table I, based on his/her expertise. The staff member then provides a lecture to the students informing them what is expected in that section. This is helpful for the students to recapitulate their learnings from previous years. Table I also shows the mark allocations for each of the topics. The total mark allocated for the project report is 300 . The students are advised to consult with the lecturers during the project. The students spend eight weeks in the MDL and complete the project. During the eight-week period, the students make use of the mine planning software that is available in the MDL as well as other related software to complete the task. The students are required to submit weekly progress reports to the Course Coordinator, in order to ensure that they are on track to complete the project.

After the project reports have been submitted, the staff members have five days to mark all the projects (a total of 19 projects in 2017). This is due to the Faculty of Engineering requirements that all the final-year marks have a submission deadline so that the graduation list can be completed. Each topic or section is marked by the lecturer who was assigned for helping the students, as discussed previously. During marking, the lecturers check that the ELO requirements have been met. Furthermore, one of the staff members, who is the
Writing and Communication Coordinator in the School, looks after the overall presentation and referencing of the report. This is an important ELO from ECSA's point of view.

The marking has to be completed before the oral presentations take place due to the time constrain. The presentation also contributes a total of 50 marks to the final marks (altogether a total of 350 marks). The distribution of marks for the presentation is shown in Table II. After randomly selecting the groups for the presentations, each group presents their findings to staff members, the external examiners, and their peer groups at the MDL. All the groups are required to upload the final copy of their PowerPoint presentation before the first day of the presentations. This is done to prevent students from making any changes to the presentations based on feedback from the other groups. The external examiners include people from the mine from where the data was obtained. This is very helpful, as not only are they fully aware of the issues at their mine, but they also look for innovative designs that the groups come up with that they can use at their mine site. Each group is given half an hour to present their findings. This is followed by 15 minutes of question time. At the end of each presentation, all marks from the staff members and the external examiners are recorded and an average group mark is calculated. All students in the same group receive the same mark.

\section{Conclusion}

This paper outlines how Wits Mining runs the Mine Design course projects. Furthermore, it establishes the connection between the ELOs and Mine Design projects. The paper emphasises the importance of using real data, along with having good facilities such as the MDL for a successful completion of the project. Crucially, successful completion of the project is an outcome of the teamwork with the various staff members in the School. This course also helps students to learn to work in groups. This study reviews the stages involved during the mine planning and design processes that were incorporated by the students during the writing up of their final report and presenting it as a group.

\section{Recommendations}

To enhance the effectiveness and use of this study, it is recommended that mine planning and design should be introduced into the curricula of universities offering Mining Engineering programmes in a way that can be applied by a multidisciplinary mine planning and design project team. This paper will assist other programmes that are trying to develop such courses. Wits Mining is currently in the process of redesigning the Mining Engineering curriculum. This will lead to further improvements in the Mine Design course.

\section{References}

Brophy, S., Klein, S., Portsmore, M., and Rogers, C. 2008. Advancing engineering education in P-12 classrooms. Journal of Engineering Education, vol. 97, no. 3. pp. 369-387.

CAmpBell, G. 1994. Geophysical contributions to mine-development planning: A risk reduction approach. Proceedings of the XV CMMI Congress, vol. 3 . Glen, H.W. and Anhaeusser, C.R. (eds.). Symposium Series no. 14. Southern African Institute of Mining and Metallurgy, Johannesburg. pp. 283-325. 


\section{Mine Planning and Design for Mining Engineering learners at Wits University}

Table I

Mine Design - allocation of marks to areas (2017)

\begin{tabular}{|c|c|}
\hline Topic & Marks \\
\hline Executive summary & 10 \\
\hline History, location, and description of project & 10 \\
\hline Mining policy, rights, licenses, ownership, and community issues & 10 \\
\hline Evaluation of the markets & 10 \\
\hline Review of geology and stratigraphy, with implications for mining & 15 \\
\hline Technical evaluation (grade-tonnage curves; Resource and Reserve statements) & 15 \\
\hline Geotechnical environment, rock engineering requirements, and design & 20 \\
\hline Review of previous design and mining method selection & 20 \\
\hline Mine design criteria, layout, and blast designs & 20 \\
\hline Production scheduling & 20 \\
\hline Equipment selection, transportation of ore, people, and materials & 15 \\
\hline Ventilation requirements and design & 15 \\
\hline Mineral processing plant requirements and design & 15 \\
\hline Ore flow accounting (incl. mine call factor - MCF) & 15 \\
\hline Surface infrastructure and load-out facilities & 10 \\
\hline Manpower requirements and productivity & 10 \\
\hline Environmental impacts, rehabilitation, and mine closure & 10 \\
\hline Economics of South African gold mining and gold mining taxation & 10 \\
\hline Financial valuation (discount rate, capital and operating costs, cash flow analysis) & 20 \\
\hline Risk analysis and key residual risks & 10 \\
\hline Conclusions and recommendations & 10 \\
\hline Referencing and overall presentation & 10 \\
\hline Total & 300 \\
\hline
\end{tabular}

Table II

\section{Mine Design - allocation of marks to presentations}

\begin{tabular}{|l|c|}
\hline Area of assessment & Marks \\
\hline Visual presentation quality & 5 \\
Audio presentation quality & 5 \\
Technical content/quality & 10 \\
Recommendations and conclusions & 10 \\
Originality and innovation & 5 \\
Appearance of presenters & 5 \\
Timing & 5 \\
Ability to answer questions & 5 \\
Total & 50 \\
\hline
\end{tabular}

Department of Minerals And EnERgy 1997. Guideline for the Compilation of a Mandatory Code of Practice for the Prevention of Coal Dust Explosions in Underground Coal Mines. Pretoria.

Engineering Council of South Africa (ECSA). 2018. Whole Qualification Standard for Bachelor of Science in Engineering (BSc(Eng))/Bachelors of Engineering (BEng): NQF Level 7

https://www.ecsa.co.za/RegisterDocuments/FileNames/(BSc(Eng)) $\% 20 \% 2$ oBachelors\%200f\%20Engineering\%20(BEng)\%20Programmes.pdf \{accessed 3 January 2018].
FouRIE, G.A. and VAN NIEKERK, D.J. 2001. Guidelines for the integrated planning and design of underground coal mines. Project no, COL 814, 1-165. November 2001. CSIR, Pretoria. http://hdl.handle.net/10204/1523

Genc, B. and CAwood, F. 2012. The establishment of a Mine Design Laboratory for improved teaching of and learning by Mining Engineering students: A case study. Journal of the Southern African Institute of Mining and Metallurgy, vol. 112. pp. 677-682.

SAYDAM, S. and Mitra, R. 2013. Implementation of final year Mining Engineering project based courses. International Journal of Learning in Higher Education, vol. 19, no. 4. pp. 91-105.

Smith, G.L., Pearson-Taylor, J., and Andersen, D.C. 2006. The evolution of strategic long-term planning at Anglo Platinum. Proceedings of the International Platinum Conference: 'Platinum Surges Ahead. Southern African Institute of Mining and Metallurgy. pp. 301-305.

Smith, G.L. and Pearson-Taylor, J. 2006. Alignment of capital and strategic intent-challenges and responses at Anglo Platinum. Proceedings of the Second International Seminar on Strategic versus Tactical Approaches in Mining, Australian Centre for Geomechanics, Perth, Australia. pp. 1-6.

Steffen, O.K.H. 1996. Planning of open pit mines on a risk basis. Proceedings of Surface Mining 1996. Symposium Series S15. Southern African Institute of Mining and Metallurgy, Johannesburg,

SAMREC. (2016). South African Mineral Resource Committee. The South African Code for the Reporting of Exploration Results, Mineral Resources and Mineral Reserves (the SAMREC Code). 2016 Edition. http://www.samcode.co.za/codes/category/8-reportingcodes? download=120:samrec [accessed 1 August 2018]. 